the captain of the fortress placed "some Dorias ${ }^{1}$ with their Pachas, who are a race low by blood, but valiant in war."

From Bocarro (dec. 13, cap. clxviii) we learn that in 1617 the captain-major Manuel Cesar marched with his troops to Hiripițiya, in the Häpitigam Kōralē, "a village of the faithless pachas," to inflict chastisement on them for their treachery.

Ribeiro (op. cit.) mentions the Pachas as a people of low caste; and from the Portuguese account of the siege of Colombo by the Dutch in 1655-6 embodied in Baldaeus's "Ceylon," it seems that Pachas were still employed in the defence of the city, as they had been seventy years before. Valentyn (op. cit.) does not enumerate them in his elaborate list of castes; and the only mention of them that I have found in his work is in a list of castes in the disavani of Colombo drawn up in 1707 by the Dessave Bolscho, where 922 "Paatjes" are entered, being preceded by "Chialiassen" (chaliyas, or cinnamon-peelers) and followed by "Hunawas" (hinnāvo, or washers for chaliyas).

The name 'Pacha,' as applied to a caste, appears to have died out in Ceylon. The word itself is simply Sinh. pajja, paja, or pajaya, "Sudra, low and wicked man, one of a degraded tribe, mischievous fellow" (Clough), the literal meaning being 'foot-born,' referring to the legendary origin of the Sudras.-Yours very truly,

Croydon, Oct. 1, $1898 . \quad$ Donald Ferguson.

\title{
4. More Light on 'Omar Khayām.
}

Dear Sir,-With reference to Professor Denison Ross's very interesting article, and to Mr. Burn's letter, I beg leave to point out that the true reading for the penultimate

1 A Durajã is a headman of the jaggery, palankin-bearer, and cinnamonpeeler castes.

2 The Portuguese diarist says: "On the 13th four Pachas deserted." This the English translator (in Churchill's "Voyages," vol. iii) renders: "The 13th we sent away four Pachas, or Advice-boats"! He evidently confounded Pachas with pataxos. 
word of the first line of the verse quoted at p. 359 of the April number is $\dot{k}$ ham and not $\rightarrow$ ham. Mr. Whinfield has shown me that this is the reading in the Lucknow edition of the quatrains, and I have since found it in three MSS. of the Târikh Alfí in the British Museum and in two in the India Office. This reading also makes better sense. What 'Omar said was, "You have gone and come back, nay, you have turned crooked," in allusion to the circumstance of the erect body of a man having been changed into the crooked or bent body of a quadruped. If the abridged copy of the Târikh Alfi referred to by Professor Schukovski be that described by Dr. Dorn in the Mélanges Asiatiques, vi, 121 , it is a very modern work, it having been written in 1834. The Tärīkh Alfī was written by the order of Akbar and dates from about 1586. The dates given in it are calculated from the death (Rihlat) of Muhammad, and so are ten years less than the Hijra dates. Hence, when 'Omar Khayām's death is placed under the year 495 in the Tārīkh Alfī this means 505 A.H. But even then the date given for the death is twelve years less than the commonly accepted one (517 A.H.).

The notice in the Tārikh Alfī is a curious one, and apparently longer than that in the abridgment used by Professor Schukovski. It begins in the same way as the extract at p. 358 of our Journal, but there seems to be some differences in the readings. 'Omar's ancestors, it tells us, came from Shamshād. The Persian of the curious passage about 'Omar's avarice is: "az wāste bakhal dar intishak-i'alūm u ținat dar taṣnîf chandān asarī namānd." The story about the three friends is not given, but the story of the donkey is, and also the anecdotes about 'Omar's quarrel with Sultān Sanjar and about his last hours.

The new date for 'Omar's death is important, for it reduces the improbability of his having been a schoolfellow of Nizām al Mulk. Both Professor Browne and Professor Denison Ross reject the story about the three friends on account of alleged anachronisms, but is it really so unbelievable? Niẓām al Mulk was born in 408 A.H., and was cut off by the haud 
of an assassin in 485 A.H. when he was about seventy-five years of age according to our calendar. Does the fact, if it be one, that Hasan died in 518 A.H., make it impossible that he should have been Nizām al Mulk's schoolfellow? We do not know how long the latter might have lived if he had not come by a violent death. At all events 'Omar Khayām might have been his contemporary, for he died in 505 A.H., or only twenty years after Niẓām al Mulk was killed. Of course, if Hasan lived till 518, he can hardly have been born in 408 , but he may have been some years younger than Nizām and still have been at school with him. It must be remembered, too, that Hasan certainly died at an advanced age, and that the period 408-518 is not so formidable in the Muhammadan calendar as in the Christian. It amounts to 106 and not to 110 years.

For convenience of reference I note the pages in the MSS. which refer to 'Omar:-

1. B.M. MS., Or. 142, pp. $300 c \& b$.

2. Do. do. Add. 16,681 , p. 526b.

3. Do. do. Add. 6,551, pp. $323 b \& 324 c$.

4. India Office MS., No. 312 (113 of Ethé), p. 280.

5. Do. do. No. 835, p. $248 b$.

P.S.-The Dastūr al Wazrā of Khhwāndamīr, a work written after the Habiba-s-suir, gives 478 as the date of Hasan Șabāh's death (B.M. MS., Or. 234, p. 906), and a notice in Schefer's Supplement, p. 56, which is put as if an extract from the Wașaya, but does not occur in that work, gives 492 as the date. Probably, however, these are both mistakes. A better defence of the story may perhaps be found in the uncertainty about the date of Niẓām al Mulk's birth. The commonly received date is 408 , but that seems to rest on the authority of Arabic writers who were far removed in place, if not in time. The local history called the Tärikh-i-Baihaq, which was written in the middle of the sixth century, gives 410 as the date (B.M. MS., Or. 3587, p. $43 a$, No. 89 of Rieu's Supplement), and the same date is given in the Nasakh 
Jahānāva (B.M. MS., Or. 141, p. 89a). Niẓām himself, in a story accepted by Gibbon, is said to have declared himself to be 93 years of age. Certainly there is nothing in what is known of his career to make it necessary that he should have been born as early as 408 . He was Prime Minister for thirty years, but he may have begun when he was thirty, and we do not hear of his being much employed in public affairs before 455 . The only employment that we hear of was at Balkh, but as he was ill-treated there he probably did not remain long before he ran away. Something, too, may be said for the verisimilitude of the story in the Wasaaya. That book cannot be older than the ninth or the end of the eighth century, but it was written by and for a descendant of the Vizier. It contains anecdotes of Alp Arslān and others, and one or two of them have been copied into the Nigāristān. Are these also inventions? Is it not more likely that the author used, as he says he did, books and family traditions, and that there is a substratum of truth in the story of the three friends? It would help us in deciding on the authenticity of the story if we knew the date of the Imām Muwaffiq who is mentioned as the teacher of the friends, but it is difficult to identify him. Häjī Khalfa (vi, 144, and iii, 316) speaks of an Imām Muwaffiq who died in 568, and Yāqūt (s.v. Bijistān) refers to an Abūl Qäsim Muwaffiq who was greatly respected in Nishapūr, and who flourished about 520. If either of these be the Muwaffiq of the Wasaya the story is false. On the otber hand, Imādu-d-din Isfahānī, in an Arabic extract given at p. 115 of M. Schefer's Supplément, quotes some one who speaks of an Imäm Al Muwaffiq who was teaching in 434, and had ' Umīd al Mulk Alkindari for a pupil. This seems to support the story. Alkindarī was Niẓām's predecessor as Vizier, and was presumably older than he, for he was the minister of a previous king. If he was at school in 434, Nị̄ām may have been a later pupil. Indeed, if the story be true, he must have been about the last pupil that Muwaffiq had, for he was then over 85 . 
I have gone into these details from a desire to support the story if possible, but I admit that the chronology is a difficulty. It is due to Mr. Whinfield to point out that the apparent anachronisms in the story were noticed by him several years ago, in the introduction to his translation of the quatrains.

\section{H. Beveridge.}

\section{ARI.}

The histories of Burma, as stated by Sir A. P. Phayre in his work, published by Trübner \& Co., p. 33, make mention of certain recluses or priests, called ARI, who conducted the religion prevalent at Pugan in the year A.D. 1000. Sir A. Phayre seems to think that they were the priests of Nāga worship, and that their "practices resembled those of the Vāmāchāris of Bengal." $\mathrm{He}$, however, makes no attempt to explain the word, and now Mrs. Bode, who does not pretend to know anything about Burmese, suggests that it may be connected with ariyo. Mr. Tawseinko says, in his notes on the Kalyāni inscriptions of King Dhammaceti of Pegu (A.D. 1469) : "A debased form of Buddhism, which was probably introduced from Northern India, existed at Pagan. Its teachers, called Arîs, were not strict observers of their vow of celibacy; and it is expressly recorded in native histories that they had written records of their doctrines, the basis of which was that sin could be expiated by the recitation of certain hymns." He, too, makes no attempt to explain this word, whose spelling ought to have attracted notice.

As given in Stevenson's Dictionary, and in the copy of Burmese history in my possession, it is spelt $3200 \%$, which properly transliterated would be araññs, but, according to the modern pronunciation of Burmese, is now ari.

If this word were pure Burmese it would be a noun formed from the verb Q either as $r \bar{i}, r e h$, or $r i \ddot{n}$, with a heavy accent. There is 